\title{
The cinematic hidden Christ - His invisible divinity and his visible humanity
}

\author{
Brinkman, Martien E \\ Stellenbosch University \\ mebrinkman1950@gmail.com
}

\begin{abstract}
If we want to reflect upon the impact of the many 'hidden Christ'- images in modern films at a theologically responsible way, we need to incorporate that reflection into our doctrine of revelation. That will imply that we have to re-open the classical GospelCulture discussion. Especially in the United States we can recognize a lot of original approaches to this issue in Reformed circles (Wolterstorff, Dyrness, Begbie, Seidell, etc.). The main question to be put in this article will be: How can we develop criteria to assess the depiction of the divine in these films?
\end{abstract}

Key words

Christology; hidden Christ; immanence; revelation; symbol; transcendence

\section{Introduction}

A hidden Christ can be considered as a fictional human being that can be seen as a new embodiment of the positive meaning that can be attributed in the present to the biblical Jesus figure. ${ }^{1}$ This meaning is usually not selfevident, and that is why I speak of the hidden Christ.

I do not intend to offer a detailed analysis of the many art expressions of this hidden Christ in current Western art. I offered some of that kind of analyses in my book on Jesus Incognito, especially of the work of the writers

1 M. E. Brinkman, Jesus Incognito: The Hidden Christ in Western Art since 1960 (Amsterdam-New York: Rodopi 2013), pp. 5 and 41. Martien E. Brinkman is professor (emeritus) of ecumenical/intercultural theology at the Vrije Universiteit, Amsterdam, The Netherlands. He published The Tragedy of Human Freedom (2003), The NonWestern Jesus (2009) and Jesus Incognito (2013). 
JM Coetzee, Peter de Vries and Arnon Grunberg, the poets Les Murray and Czeslaw Milosz and the artists Andy Warhol, Frans Franciscus and Harald Duwe. Here I limit myself to the reflection upon the potential Christological impact of (also in the above-mentioned book analysed) films as Babette's Feast (1987) of Gabriel Axel, The Communicants (1963) of Ingmar Bergman, A Short Film about Love (1989) of Krzysztof Kieslowski and Breaking the Waves (1996) of Lars von Trier. The four main protagonists in these films, Babette, Tomas, Tomek and Bess, can be considered as hidden Christ figures. In this article I shall not repeat my analysis of these films. More than in the above-mentioned book I shall present a theological evaluation of their potential Christological impact. I intend to bring in touch two totally different fields of reflection: that of modern cinematology and that of current Dogmatics. I undertake this enterprise in the hope that this dialogue could throw some new light on classical discussions on revelation, the divine and the humane. Therefore, I ask: How do modern artists point to the divine dimension of Jesus' life? How do they depict the divine? As said, I shall concentrate upon the so-called hidden Christ films ${ }^{2}$, but most of what will be said in reference to them, can also be said about the hidden Christ in literature and the visual arts. ${ }^{3}$

In the more or less classic Jesus-films (e.g. The Gospel According to St. Matthew of Pasolini, Jesus Christ Superstar of Jewison, The Last Temptation of Christ of Scorsese and The Passion of the Christ of Gibson), the so-called biopics, Jesus' divine dimension is always already presupposed. That dimension is considered to be well-known. But that Jesus differs from the Jesus of the New Testament. There his divinity was still a point of dispute. Even to the disciples he remained a Jesus incognito for a long time. People constantly wondered who he was. Who among us would have recognized him? It is not immediately apparent that he is the Son of God. His divine

2 See among others, W. B. Tatum, Jesus at the Movies: A Guide to the First Hundred Years(Santa Rosa: Polebridge Press, 2004); R. C. Stern, C. N. Jefford and G. Debona, Savior on the Silver Screen(New York: Paulist Press 1999); C. Deacy, "Screen Christologies: An Evaluation of the Role of Christ-figures in Film". The Journal of Contemporary Religion 14 (1999): 325-337 and A. Reinhartz, Jesus of Hollywood (New York: Oxford University Press 2007).

3 R. Detweiler, “The Christ Figure in American Literature' in: M. E. Marty and D. G. Peerman (eds.), New Theology, Vol. II (New York-London: Macmillan 1965), 297-316 and K.-J. Kuschel, The Poet as Mirror: Human Nature, God and Jesus in TwentiethCentury Literature (London: SCM Press 1999). 
descent is at several occasions object of explicit discussion (Matt. 4: 3 and 6; 26: 63 and 27: 40 and 43). Something similar can be said with respect to the hidden Christ in modern films. In that sense the so-called hidden Christ films are more biblical than the Jesus-films in spite of their often high claims of biblical faithfulness. ${ }^{4}$

\section{Imaging the Divine}

How can the divine be imagined in our de-divinized, secularized, modern world? ${ }^{5}$ How can we imagine God when we do not have anymore any remembrance of Him? That was already a crucial question for Augustine. ${ }^{6}$ If we, however, do no longer have any images for the divine, we have, in fact, also no more images and words for the mystery of Jesus. The mystery of Jesus has everything to do with the fact that we cannot speak about the divine in him without the human and not about the human without the divine. That is the divine-human mystery that he embodies according to the early creeds of the ancient church. Therefore, the question how to depict the divine confronts us immediately also with the question how to depict the human. ${ }^{7}$

It is impossible to indicate in a straightforward fashion what is divine and what is human. No one can say definitively: that is typically divine, and that is pre-eminently human. So, we can repeat another question of Augustine as well: "What is it that I love in loving thee?"8 John 1:18 told us already: "No one has ever seen God". Where on earth can we find pointers to God's presence?

4 P. V. M Flesher and R. Torry, "Filming Jesus: Between Authority and Heresy". The Journal of Religion and Film 8 (2004): 1-19. See for the difference between the socalled hidden Christ films and Jesus films, A. Reinhartz, "Jesus und Christ-Figures", in J. Lyden (ed.), The Routledge Companion to Religion and Film (London-New York: Routledge 2009), pp. 420-439.

5 L Baugh, Imaging the Divine: Jesus and Christ-figures in Film (New York: Rowman \& Littlefield Publishers 1997).

6 Augustine, Confessions X.17.

7 G. Finaldi, The Image of Christ (London: National Gallery Company 2000), p. 45: “The most difficult task for the artist seeking to represent Christ is how to depict his dual nature: fully human and fully divine."

8 Augustine, Confessions X.6. 
That is not just a modern question. Already in the Old Testament the place where God can be found, is point of discussion. How directly do we encounter God in his temple, in his deputies, the kings, in the words of the prophets, in the Torah? Sometimes some developments in interpretation can be traced in the Old Testament itself, but in other cases there is an ongoing discussion, for example with regard to the difference between false and true prophets. Like in Old Testament times, in our own current world experience nothing can be straightforwardly connected to God: each reference to God will be indirect and presuppose an interpretative framework.

\section{What about the humane?}

Does that also hold true for locating the humankind? It does not obtain, of course, for empirical human beings, but it does for what can be viewed as belonging to the core of humankind. The question asked about humankind in Psalm 8:4, "What is man that you are mindful of him, the son of man that you care for him?" is as open a question as that about God. The question of God is not only a question put by the human being but also one to the human being. Who are you? Where are you?

Even though we cannot give a cut-and-dried answer, we continue, christologically speaking, to search for the truly human in the divine and the truly divine in the human. We seek true man in God and true God in man. ${ }^{10}$ The question about God is also the question about humankind, and vice versa. The meaning of the historical Jesus as true man can, therefore, be fathomed only if we see in him a reference to God as well. And who God is can be fathomed only by looking at this man. They thus presuppose each other. If we realize this, also our human existence in the identification with Jesus seems to be an open existence as well: open for experiences that transcend our empirical existence. Apparently the immanent frame within which the secularized Western human person has closed himself, can be broken through. Theologically we speak then from revelation.

9 A. Houtepen, God: An Open Question (London: Continuum 2002).

10 E Jüngel, "Humanity in Correspondence to God: Remarks on the Image of God as Basic Concept in Theological Anthropology", in Theological Essays, Vol. I (Edinburgh: T and T Clark 1989), pp. 124-153. 


\section{Religious interpretations of films}

The recognition of, for example, the religious dimension of a film often involves a certain symbolic interpretation of everyday reality. It is never a matter of an initially immediately obvious interpretation. In the Middle Ages, it was held that the 'book of nature' was of a piece with 'the book of revelation' (the Bible). Nature was, as it were, an open book. God could be recognized in it. Nowadays, at least, it can be said that straightforward pointers to God in nature are contested. But that does not mean that our experience of reality is now completely one-dimensional.

In line with an important school of thought in symbol theory ${ }^{11}$ and the theology of the sacraments ${ }^{12}$ one finds a great deal of discussion in the literature on film on the simultaneity of the presence and absence of the symbolized in the symbol. This recognition of the concealing and revealing character of symbols has everything to do with the deep human experience that the referential character of everyday reality is never univocal but always ambivalent. Only seldom does reality speak clearly.

Theology has to take that ambivalence into account, as do films. Nonetheless, a film can evoke a high degree of openness for symbolic interpretations. ${ }^{13}$ Hidden Christ films especially appeal to that. That openness can be created in all kinds of ways, but in films this is often done in a striking way by evoking contrast experiences. Thus, as it were, an appeal is made silently 'from out of the depths' (de profundis) of human existence to something that could transcend it. Darkness appears to evoke light. Intriguing examples of this approach are films like A Short Film of Love (1989) of the Polish filmmaker Krzystof Kieslowski and Breaking the Waves (1996) of the Danish director Lars von Trier. 'Descent' then in fact constitutes the only possibility of referring to something higher (ascent). ${ }^{14}$ 'Ascent' is thus

11 P. Ricoeur, The Symbolism of Evil (New York: Harper \& Row 1967), pp. 10-18.

12 L.-M. Chauvet, Du Symbolisme au Symbole: Essai sur les Sacrements (Paris: Cerf 1979), 77-79 and 91-93; Idem, Symbole et Sacrement: Une Relecture Sacramentelle de l'Existence Chrétienn (Paris: Cerf 1988), 85-115 and Groupe des Dombes, L'Esprit Saint, l'Église et les Sacrements (Taizé: Presse de Taizé 1979), pp. 36 and 57.

13 J. R, May, "Visual Story and the Religious Interpretation of Film", in J. R. May and M. S. Bird (eds.), Religion in Film (Knoxville: University of Tennessee Press 1984), pp. 23-43.

14 E. Ferlita, "The Analogy of Action in Film”, in J. R. May and M. S. Bird (eds.), Religion in Film, pp. 44-57, esp. p. 54. 
a typical activity of the viewer on whom a film that begins below makes such an impression that the viewer's thoughts transcend it of themselves. Those thoughts can be the continuations of the images in the film but can, in contrast, also form the contrast of themselves. That character of some images to evoke contrasts can go beyond the filmmaker's intention. It can even be in explicit conflict with his intention. ${ }^{15}$ It is the viewer who takes these steps.

\section{Rearrangement}

A rearrangement of images is constantly occurring in art, also with respect to the Christ figure. The public is being invited more and more to make their own identifications and distinctions between the Christ figure presented and the reality to which he refers. It thus always concerns a 'refigured' Christ. ${ }^{16}$ The word 'refiguration' has been stamped in recent decades by the French philosopher Paul Ricoeur. In connection with the analysis of literary texts, he developed the well-known triad of prefiguration, configuration, and refiguration. ${ }^{17}$ Applied to the person of Christ, this means that each writer always encounters a "Christ reality" that is already present. This prefigured reality constitutes his material that he configures to his own interpretation. The reader then looks at that and constructs his own reality from that. He appropriates the text existentially. That is the reader's own refiguration. To prevent this last step from being explained as a cheap 'running away with' the text, Ricoeur also speaks emphatically, when describing this appropriation process, of the continuing strangeness of texts. Appropriation is not a simple identification. It always concerns understanding through and at a distance, recognizing the strange, the other that a literary text presents. Ricoeur considers that recognition to be a condition for understanding. Otherwise, understanding becomes annexation. ${ }^{18}$

15 Ibid., pp. 55-56.

16 L. Baugh, Imaging the Divine, pp. 3-6 and pp. 234-237.

17 P Ricoeur, Time and Narrative, Vol. I (Chicago: University of Chicago Press 1984), pp. 52-87.

18 Idem, Interpretation Theory: Discourse and the Surplus of Meaning (Fort Worth: Texas Christian University Press 1976), pp. 91-94. 
In line with his attention for the continuing strangeness of a text, Ricoeur also emphasizes that a text always refers to a certain real reality. That reality cannot be manipulated by the writer or by the reader. It transcends both. A text is not much more than 'a suggestion for a world' in which the reader can live only temporarily. ${ }^{19}$ It is not reality itself. Applied to the significance that is attributed to Jesus, this means that literary, cinematic, and other artistic images always refer to a reality that transcends the meaning we give to it. That is what is at issue in the refigured Christ. It always refers to a reality that transcends that of the artist and that of the audience. But that does not exclude the fact that both can become active in the process of attributing meaning.

\section{A Christology 'from below'}

What is exciting about these hidden Christ films is thus, again and again, the way in which the divine is depicted in everyday life. Sometimes, a filmmaker uses traditional symbols like a storm, thunder, or lightning (this accompanies Babette's arrival in Babette's Feast (1987) or the ringing of bells in heaven (which can be heard at the day of Bess' burial at sea in Breaking the Waves), but usually they use more original, surprising references.

We often see a reference to an interpersonal experience. Usually, it is an experience of the 'too much'. Sometimes, only a glance or a mere gesture indicates that experience. These openings have everything to do with what is called revelation in the Christian tradition. ${ }^{20}$ Each encounter with the Christ figure always involves that experience. In that encounter, the boundaries of what it is to be human are explored and also sometimes shifted and thus broken through. 'From below' and 'from above' come together, and then the Christological miracle occurs.

Theologically, that experience has everything to do with incarnation. That is always a twofold experience. On the one hand, it is the experience of making room for, of emptying (kenosis), of the death of the old Adam, of becoming internally empty. In that sense, it is a matter of the art of

19 Ibid., 94.

20 J.-L. Marion, The Visible and the Revealed (New York: Fordham University Press 2008), pp. 18-48 and pp. 119-121. 
letting go. On the other hand, it is an experience of renewed fulfilment, of resurrection, of being born again. In the Christian tradition, this twofold experience is called 'dying and rising with Christ' (Colossians 2:12). It is brought to symbolic expression in the sacraments of Baptism and The Lord's Supper. Deliberately I am therefore linking incarnation primarily with the event of dying and rising and not just with the affirmation of the human aspect. ${ }^{21}$ Incarnation implies, therefore, transformation and presupposes a two-fold movement, namely of kenosis and fulfilment, of negation and affirmation. ${ }^{22}$

The religious aspect of films can thus not be separated from everyday experiences. Every film that leaves the possibility open of a reference to a hidden Christ will always start with his humanity. Human behaviour will be central in such a film. In theological jargon, this means that it is always primarily a Christology 'from below'. ${ }^{23}$ That is given with the Christian belief in the incarnation, the Word becoming flesh. That is why, from a Christian point of view, the perception of our everyday reality can also be suggestive. It can contain hints of another reality. To quote T.S. Eliot冈s Four Quartets: "The hint half guessed, the gift half understood, is Incarnation." ('The Dry Salvages')

The hidden Christ is thus never an obvious Christ. Even in the New Testament it was not obvious that Jesus was the Christ, often he was not recognized as such. In addition to devices and artifices, filmmakers have two methods at their disposal for revealing a personage's Christ-like character: the method of positive similarity or that of negative contrast. Babette, the main protagonist in Babette's Feast, and Tomek in A Short Film about Love are examples of the first method. David, one of the two protagonists in Steve Jakobs' film Disgrace (2009), based upon J.M. Coetzee's novel with the same title (1999), is an excellent example of the second method. Both

21 M. E. Brinkman, Sacraments of Freedom (Zoetermeer: Meinema 1999), pp. 64-68.

22 J. Begbie, Voicing Creation's Praise: Towards a Theology of the Arts (Edinburgh: T \& T Clark 1991), p. 214 and also M. E. Brinkman, Jesus Incognito, p. 49.

23 Strictly speaking it makes no sense to speak of a Christology 'from above' and 'from below', because - as said above - the essence of every Christology is the mystery of the interaction of 'above' and 'below'. Notwithstanding this generally acknowledged fact, theologians often continue to use these two labels to discern two different approaches in Christology. 
methods have their pros and cons. Similarity usually brings with it a great deal of insightfulness but can also become too direct and thus too onedimensional. The contrast method is usually more surprising, but the contrast can also be so crushing that it no longer evokes anything-the one extreme does not always immediately evoke the other.

\section{Characteristics of the Christ figure}

Although I am inclined to admit that an objective, cinematic Christ figure does not exist, ${ }^{24}$ I do need to have in mind some kind of a blueprint that can serve as a working hypothesis in order to be able to begin a quest for the hidden Christ. Therefore, my proposal is to focus on four main and classical characteristics. They can be considered as more or less the summary of the Gospels and the creeds of the ancient church. As main aspects of Jesus' life I would like to point to his divine calling, his message of the coming Kingdom, the sacrifice of his life as implication of his calling and his resurrection. He felt himself called by God to announce the risky message of a radically different world, implying his own death, but confident of the completion of his life after his death.

In my proposal there is room for the mystery that the figure of Jesus Christ embodies according to the Christian tradition, namely the simultaneousness of his divine and human nature. Such a proposal is not meant to limit the artistic freedom in any way. It is not a frame imposed by an institution (the church). And the four above-mentioned identity markers do not all have to appear simultaneously. One of them can sometimes be so prominent that it is more than sufficient in itself to evoke the association with the Christ figure. They are nothing more than a tool for analysis. To be able to speak about a Christ figure a certain number of the characteristics mentioned here will have to be present in a sufficiently striking way and determine the life of the figure in question to a large extent. ${ }^{25}$

24 C. Deacy, "Reflections on the Uncritical Appropriation of Cinematic Christ-Figures: Holy Other or Wholly Inadequate?" Journal of Religion and Popular Culture 13 (Summer 2006): 1-16.

25 P. Malone, "Jesus on Our Screens", in J. R. May (ed.), New Image of Religious Film (Kansas City: Sheed and Ward 1997), pp. 57-71, esp. pp. 69-70. 
What is stated above can be explained by the well-known difference, in the philosophy of science, between a context of justification and discovery. The four identity markers of Jesus' life belong to the context of justification. What actually is observed in a film, belongs to the context of discovery of the viewer, to his concrete context of life. ${ }^{26}$

\section{The Jesus and the Christ figure}

I connected the transcendent (divine) aspect with the four identity markers of Jesus' life (calling, message, death and resurrection). There his identity as a revealer of divine nearness can be found. How we exactly should understand God's revelation (in the midst of concealment) in him is still a difficult question. Does it concern the revelation of a truly new aspect, never experienced in any person before him? Or is it the revelation of the reference character of that was hidden at first? Is it sometimes the nearness of the strange other whose existence we know only at a distance? Or is the revelatory aspect found precisely in the fact that naked human existence conceals nothing? ${ }^{27}$ We do not need to opt for one of these four options, although it will be clear that in the case of the first option (of radical transcendence), it would not make sense to speak of a hidden Christ. The last three options can easily be recognized in the so-called hidden Christ films.

Of course, the Christ figure and the historical Jesus figure cannot be separated, not in the reality of believers nor in the conceptualization of artists. The list of noless than 25 characteristics of the Christ figure compiled by the Australian film critic Anton Karl Kozlovic is a good example of this interconnectedness. ${ }^{28}$ These characteristics, however, contribute only in a limited way to the process of giving meaning. We must go beyond

26 H. Reichenbach, Experience and Prediction. An Analysis of the Foundations and the Structure of Knowledge (Chicago: The University of Chicago Press 1938), p. 33.

27 These four options can be connected with four different types of transcendence: radical transcendence, immanent transcendence, transcendence of the other and radical immanence, respectively. Cf. W. Stoker, "Culture and Transcendence: A Typology", in W. Stoker und W. L. van der Merwe (eds.), Looking Beyond? Shifting Views of Transcendence in Philosophy, Theology, Art, and Politics (Amsterdam-New York: Rodopi 2012), pp. 5-28.

28 A. K. Kozlovic, "The Structural Characteristics of the Cinematic Christ-Figure". Journal of Religion and Popular Culture 8 (Fall 2004): 1-71. 
the assertion of all kinds of parallels between film figures and the biblical Jesus. ${ }^{29}$ The attribution of meaning does not come about by compiling a kind of checklist of parallels but is fully dependent on the capacity of the individual viewer to make up his mind. It is connected with what the film presents and what the viewer discovers regarding these presentations of Christ.

A creative interaction between these two poles can lead to new contemporary interpretations of the Jesus figure. Then, in my view, a Jesus figure becomes a Christ figure, i.e. a contemporized Jesus figure. ${ }^{30} \mathrm{I}$ am speaking intentionally of a Christ figure and not of a Christ principle. ${ }^{31}$ The word 'figure' refers here to a concrete (be it also fictive) person who speaks and acts. The word thus intentionally evokes associations with the Old Testament prefigurations of Jesus in, for example, Adam, Joshua, Joseph, and David.

Perhaps, when discussing cinematic Christ figures, we could speak of post-figurations. In both pre- and post-figurations the typology is always only absorbed to a certain extent. The various types always show just a certain aspect of the figure who is central. He himself is the only one who completely embodies the image. Pre- and post-figurations are thus never identical to him but are always more or less identifiable with him. The Christ figure is constantly found at the interface of identity and nonidentity with the historical Jesus figure. It does not, therefore, make much sense to argue that the cinematic Christ figure is distinct from the historical Jesus figure. That is logical and inherent to the idea of post-figuration. It is more important to search for the similarities. Cinematic Christ figures always concern concretely presented fictional human individuals who, as independent film characters, point to the contemporary meaning of the Jesus figure. ${ }^{32}$ By alluding to the Jesus figure, the filmmaker (or viewer)

29 C. Deacy, 'Reflections on the Uncritical Appropriation', p. 4.

30 M. E. Brinkman, Jesus Incognito, p. 41.

31 In modern Indian theology, e.g., we can recognize a certain preference to speak about a 'christic principle' instead of about the concrete person of Jesus Christ. Cf. R. Panikkar, Trinity and the Religious Experience of Man (Maryknoll: Orbis 1973), 54 and 68. See also, M. E. Brinkman, The Non-Western Jesus: Jesus as Bodhisattva, Avatara, Guru, Prophet, Ancestor or Healer? Cross Cultural Theologies (London: Equinox 2009), pp. 149-157.

32 ME Brinkman, Jesus Incognito, p. 41. 
introduces an additional depth dimension to this (in him- or herself) fullyfledged character. ${ }^{33}$ As an independent character, the cinematic Christ figure is more than a 'mere' imitator of Jesus. Such a figure also points to the meaning of the person of Jesus. He does not do so as the homo optimus, the ideal human being, or as the embodiment of the condition humaine in general. Rather, he is the homo proximus, the human form that most closely approximates the words and deeds of Jesus and thus also confronts us with the divine nearness in Jesus. The Christ figure usually includes just enough aspects to break through the immanent frame of our secular mind and thus to create the possibility of reflecting anew on our own existence in the light of the God-human mystery that Jesus personifies. ${ }^{34}$

I am not looking for an archetypal redeemer whose characteristics can be recognized in other religions. My first concern is a theological evaluation of what happens between film and theology with respect to the Jesus figure. I am convinced that the religious "disenchantment" (Entzauberung) of our worldview (Max Weber) has occurred only in part. A purely naturalistic approach to reality remains unsatisfactory for many artists. ${ }^{35}$ One can even point, perhaps, to a re-enchantment, although without so far an extended, theoretical basis. There is still a theoretical 'loneliness' to which many artists condemned themselves in the previous century. ${ }^{36} \mathrm{I}$ do not want to give that loneliness the final word, for it is still possible that similarities can be discovered between the central questions that lie at the foundation of Christianity and those that modern Western art has raised at regular intervals. There could be an 'analogical imagination'. ${ }^{37}$

Actually, theological ideas are then 'given back' to theology anonymously (incognito) by art. They are thus not lost but found in translation. The artistic depiction is then not a betrayal but a portrayal. The phrase Jesus incognito receives then such a positive connotation that I would like to speak of a

33 Chr. Downing, "Typology and the Literary Christ-Figure: A Critique". The Journal of the American Academy of Religion 36 (1968): 13-27, esp. 25-26.

34 R Detweiler, 'The Christ Figure in American Literature', pp. 312-315.

35 D. Morgan, 'Enchantment, Disenchantment, Re-Enchantment', in J. Elkins and D. Morgan (eds.), Re-Enchantment (London: Routledge 2009), pp. 3-22, esp. pp. 9-14.

36 J Begbie, Voicing Creation's Praise, pp. 186-204.

37 D. Tracy, The Analogical Imagination: Christian Theology and the Culture of Pluralism (New York: Crossroad 1981) and E. Ferlita, 'The Analogy of Action in Film', pp. 44-57. 
hidden Christ. Apparently, there is "a compelling mysterious force within the creative human imagination that shapes fictional characters and dramatic plots in the image and likeness of the central character and events of the four Gospels of Matthew, Mark, Luke, and John." ${ }^{38}$ That brought me precisely to the 'fictional character' that I referred to as the hidden Christ.

\section{Just a fictional figure?}

Some might protest here. Is it all just about fiction? Are fictional figures able to represent the salvific meaning of Jesus Christ? How useful the concept of fiction here is, depends, of course, on our description of fiction. Let me quote here Nicholas Wolterstorff: 'by way' of fictionally projecting his distinct world the fictional may make a claim, true or false as the case may be, about our actual world. ${ }^{39}$ That means that the projected world of an artist bears the potential of showing us something of the actual world. Hence, Jeremy Begbie states: "A work of art, even if fictional, may lead us to change our attitude to the states of affairs with which it deals and which inform our day to day lives. This is not a case of confusing the imagined world with the real world, but of having our experience of the everyday world enriched and illuminated by the imagined world." 40

Sooner or later all art interpretations that point to an openness for Christian interpretations must be brought into connection with the three guiding principles of Christian hermeneutics: the Bible, the Christological creeds of the ancient Church and the central elements of the current Christian liturgy. In essence, these guiding principles obtain for all world religions. It concerns the relation to the holy book(s), the tradition and the contemporary experience. The question if something fits within a certain religion will always be decided on the basis of the holy text(s), the more or less sanctioned interpretations of it in the course of its history and the actual experience of it in regular celebrations. This interaction is needed, not to force them into a straitjacket but to initiate a dialogue

38 N. P. Hurley, "Cinematic Transfigurations of Jesus" in: J. R. May and M. S. Bird (eds), Religion in Film, pp. 61-78, esp. p. 75.

39 N. Wolterstorff, Art in Action: Towards a Christian Aesthetic (Grand Rapids: Eerdmans 1980), p. 125.

40 J. Begbie, Voicing Creation's Praise, p. 252. 
between historical and modern interpretations. Otherwise, (the history of) theology and art remain closed off from each other. One could speak here of the possibility of a two-sided transformation ${ }^{41}$ New interpretations can throw new light on the Christian tradition, which will in turn provide depth to new interpretations and sometimes supplement them (critically or not). ${ }^{42}$ Actually, that means not only that the Christ figure continually receives new meanings in new art forms but also that the same Christ figure influences new interpretations from his own historical and contemporary expressive power. It thus has to do with a continuous interaction, with really two way traffic. ${ }^{43}$ Therefore, by speaking about two-sided transformation I underscore the transformative power of art as well as that of Christ. ${ }^{44} \mathrm{By}$ speaking here of interaction we are taking seriously our own culture as a source of theology, provided, that the four above-mentioned identity markers of Jesus can be applied in a substantial way.

\section{Two-sided transformation}

New artistic forms can contain hidden allusions to the role of central characters and events in the four gospels. ${ }^{45}$ Why, as Christians, should we be content to see Christ only there where we expect to see him? ${ }^{46}$ That entails not only that the New Testament can be applied to understand cinematic interpretations of Christ but also that these interpretations can also be applied in turn to understand the New Testament from the perspective of

41 The idea of the two-sided transformation is the key concept of my books on The NonWestern Jesus (17-23) as well as on Jesus Incognito (46-54).

42 C. Deacy, "Redemption", in J. Lyden (ed.), The Routledge Companion to Religion and Film (London-New York: Routledge 2009), pp. 351-367, esp. pp. 358-359.

43 Idem, 'Reflections on the Uncritical Appropriation', pp. 13-16.

44 See also, R. K. Johnston, Reel Spirituality: Theology and Film in Dialogue (Grand Rapids: Baker Academic 2006), p. 251: "Here the theological dialogue needs to take both critical polls into account. That is, the portrayal of the Christ-figure by the movie adds new understanding to who Christ is. It needs to be considered on its own terms. At the same time, because the biblical portrayal of Christ has been used metaphorically, the Christ-story can clarify the character's situation and add depth and authority to the characterization. It too has a place at the critical table."

45 N. P. Hurley, 'Cinematic Transfigurations of Jesus', p. 75 and A. K. Kozlovic, 'The Structural Characteristics of the Cinematic Christ-Figure', p. 6.

46 D. A. Seidell, God in the Gallery: A Christian Embrace of Modern Art (Grand Rapids: Baker Academic 2008), p. 74. 
our contemporary culture. It is in this context that the notion of reversing the hermeneutical flow comes up. ${ }^{47}$ It means, that the hermeneutical flow moves not only from the text to the context, but also from the context to the text. In the history of Christianity there are many examples that artistic works and sometimes philosophical reflections played an important role in the existential interpretation of Bible texts. ${ }^{48}$ One could think here of Bach's Matthew and John Passions, but also of Rembrandt's famous depiction of the return of the Prodigal Son (Luke 15:11-32) and Kierkegaard's explanations of Abraham's willingness to sacrifice Isaac (Genesis 22:1-19) in Fear and Trembling. Karl Barth would for sure point here to Mozart. ${ }^{49}$

\section{Conclusion}

I am convinced that new images can be added from films to the familiar biblical ones in a way similar to what repeatedly happened throughout church history in other art areas like philosophy, music, painting and literature. In Eastern Orthodoxy especially, it is a widely held notion that the (charismatic) icon painter educates through his icons not only ordinary believers but theologians as well. A two-way street has always been presupposed there. Believers approach the icons, but the icons approach the believers as well. Hence, instruction into icon art is included in theological education in Eastern Orthodoxy. Film could also partly fulfil this role of icons. Of course not all films by far could assume that role or be up to it. But in any case, it cannot be denied that films are also sources of the attribution of meaning. Films and the Bible can then be mutually clarifying. Knowledge of the New Testament can contribute to the understanding of the Christ figure in film, but the Christ figure in film can, in turn, also contribute to the understanding of the New Testament Jesus. The latter

47 L. J. Kreitzer, The New Testament in Fiction and Film: On Reversing the Hermeneutical Flow (Sheffield: JSOT Press 1993); Idem, Gospel Images in Fiction and Film: On Reversing the Hermeneutical Flow (London: Sheffield Academic Press 2002), p. 8; C. Deacy, 'Reflections on the Uncritical Appropriation', 14 and RK Johnston, Reel Spirituality, p. 253.

48 L. J. Kreitzer, The New Testament in Fiction and Film, pp. 151-152.

49 K. Barth, "Wolfgang, Amadeus Mozart, Zürich 1956", trans. by W.M. Mosse, in W. Leibrecht (ed.), Religion and Culture: Essays in Honor of Paul Tillich (London: Harper \& Brothers 1959), pp. 61-78. See also C. Gunton, 'Mozart the Theologian', Theology, 94, no. 761 (1991): 346-349. 
has been neglected far too long in theology - to its detriment. In the near future, much will depend on the theological and spiritual sensitivity to develop a more elaborated Christian hermeneutics of modern art. ${ }^{50}$

\section{Bibliography}

Barth, K. “Wolfgang, Amadeus Mozart, Zürich 1956”, trans. by W.M. Mosse, in W. Leibrecht (ed.), Religion and Culture: Essays in Honor of Paul Tillich (London: Harper \& Brothers 1959), 61-78.

Baugh, L. Imaging the Divine: Jesus and Christ-figures in Film (New York: Rowman \& Littlefield Publishers 1997).

Begbie, J. Voicing Creation's Praise: Towards a Theology of the Arts (Edinburgh: T \& T Clark 1991).

Brinkman, M. E. Sacraments of Freedom (Zoetermeer: Meinema 1999).

Brinkman, M. E. The Non-Western Jesus: Jesus as Bodhisattva, Avatara, Guru, Prophet, Ancestor or Healer? Cross Cultural Theologies (London: Equinox 2009).

Brinkman, M. E. Jesus Incognito: The Hidden Christ in Western Art since 1960 (Amsterdam-New York: Rodopi 2013).

Chauvet, L.-M. Du Symbolisme au Symbole: Essai sur les Sacrements (Paris: Cerf 1979).

Chauvet, L.-M. Symbole et Sacrement: Une Relecture Sacramentelle de l'Existence Chrétienn (Paris: Cerf 1988).

De Gruchy, J. W. Christianity, Art and Transformation (Cambridge: Cambridge University Press 2001).

50 The building blocks are already there, see J. W. de Cruchy, Christianity, Art and Transformation (Cambridge: Cambridge University Press 2001); Idem, 'Holy Beauty: A Reformed Perspective on Aesthetics within a World of Ugly Injustice', in B. A.Gerrish (ed.), Reformed Theology for the Third Christian Millennium (Westminster: John Knox Press 2003), pp. 13-25; W. A. Dyrness, Reformed Theology and Visual Culture: The Protestant Imagination from Calvin to Edwards (Cambridge-New York: Cambridge University Press 2004) and the in this article already mentioned works of N. Wolterstorff, J. Begbie, D. A. Seidell and W. Stoker. 
De Gruchy, J. W."Holy Beauty: A Reformed Perspective on Aesthetics within a World of Ugly Injustice", in B. A.Gerrish (ed.), Reformed Theology for the Third Christian Millennium (Westminster: John Knox Press 2003), 13-25.

Deacy, C. "Screen Christologies: An Evaluation of the Role of Christfigures in Film". The Journal of Contemporary Religion 14 (1999): $325-337$.

C. Deacy, "Reflections on the Uncritical Appropriation of Cinematic Christ-Figures: Holy Other or Wholly Inadequate?” Journal of Religion and Popular Culture 13 (Summer 2006): 1-16.

Deacy, C. “Redemption”, in J. Lyden (ed.), The Routledge Companion to Religion and Film (London-New York: Routledge 2009), 351-367.

Detweiler, R. "The Christ Figure in American Literature", in M. E. Marty and D. G. Peerman (eds.), New Theology, Vol. II, (New York-London: Macmillan 1965), 297-316.

Downing, Chr. “Typology and the Literary Christ-Figure: A Critique”. The Journal of the American Academy of Religion 36 (1968) 13-27.

Dyrness, W. A. Reformed Theology and Visual Culture: The Protestant Imagination from Calvin to Edwards (Cambridge-New York:

Cambridge University Press 2004).

Ferlita, E. “The Analogy of Action in Film”, in J. R. May and M. S. Bird (eds.), Religion in Film, 44-57.

Finaldi, G. The Image of Christ (London: National Gallery Company 2000).

Flesher, P. V. M and Torry, R. "Filming Jesus: Between Authority and Heresy". The Journal of Religion and Film 8 (2004): 1-19.

Groupe des Dombes, L'Esprit Saint, l'Église et les Sacrements (Taizé: Presse de Taizé 1979).

Gunton, C. “Mozart the Theologian”. Theology 94, no. 761 (1991): 346-349. Houtepen, A. God: An Open Question (London: Continuum 2002). 
Hurley, N. P. "Cinematic Transfigurations of Jesus", in J. R. May and M. S. Bird (eds), Religion in Film, 61-78.

Johnston, R. K. Reel Spirituality: Theology and Film in Dialogue (Grand Rapids: Baker Academic 2006).

Jüngel, E. "Humanity in Correspondence to God: Remarks on the Image of God as Basic Concept in Theological Anthropology", in Theological Essays, Vol. I (Edinburgh: T and T Clark 1989), 124-153.

Kozlovic, A. K. "The Structural Characteristics of the Cinematic ChristFigure". Journal of Religion and Popular Culture 8 (Fall 2004): 1-71.

Kreitzer, L. J. The New Testament in Fiction and Film: On Reversing the Hermeneutical Flow (Sheffield: JSOT Press 1993).

Kreitzer, L. J. Gospel Images in Fiction and Film: On Reversing the Hermeneutical Flow (London: Sheffield Academic Press 2002).

Kuschel, K.-J. The Poet as Mirror: Human Nature, God and Jesus in Twentieth-Century Literature (London: SCM Press 1999).

Malone, P. “Jesus on Our Screens”, in J. R. May (ed.), New Image of Religious Film (Kansas City: Sheed and Ward 1997), 57-71.

Marion, J.-L. The Visible and the Revealed (New York: Fordham University Press 2008).

May, J. R. "Visual Story and the Religious Interpretation of Film", in J. R. May and M. S. Bird (eds.), Religion in Film (Knoxville: University of Tennessee Press 1984), 23-43.

Morgan, D. 'Enchantment, Disenchantment, Re-Enchantment', in J. Elkins and D. Morgan (eds.), Re-Enchantment (London: Routledge 2009), 3-22.

Panikkar, R. Trinity and the Religious Experience of Man (Maryknoll: Orbis 1973).

Reichenbach, H. Experience and Prediction. An Analysis of the Foundations and the Structure of Knowledge (Chicago: The University of Chicago Press 1938). 
Reinhartz, A. Jesus of Hollywood (New York: Oxford University Press 2007).

A. Reinhartz, "Jesus und Christ-Figures", in J. Lyden (ed.), The Routledge Companion to Religion and Film (London-New York: Routledge 2009), 420-439.

Ricoeur, P. The Symbolism of Evil (New York: Harper \& Row 1967).

Ricoeur, P. Interpretation Theory: Discourse and the Surplus of Meaning (Fort Worth: Texas Christian University Press 1976).

Ricoeur, P. Time and Narrative, Vol. I (Chicago: University of Chicago Press 1984).

Seidell, D. A. God in the Gallery: A Christian Embrace of Modern Art (Grand Rapids: Baker Academic 2008).

Stern, R. C. Jefford, C. N. and Debona, G. Savior on the Silver Screen (New York: Paulist Press 1999).

Stoker, W. "Culture and Transcendence: A Typology", in W. Stoker und W. L. van der Merwe (eds.), Looking Beyond? Shifting Views of Transcendence in Philosophy, Theology, Art, and Politics (AmsterdamNew York: Rodopi 2012), 5-28.

Tatum, W. B. Jesus at the Movies: A Guide to the First Hundred Years (Santa Rosa: Polebridge Press, 2004).

Tracy, D. The Analogical Imagination: Christian Theology and the Culture of Pluralism (New York: Crossroad 1981).

Wolterstorff, N. Art in Action: Towards a Christian Aesthetic (Grand Rapids: Eerdmans 1980). 